\title{
DEVELOPMENT AND UTILIZATION OF OPEN INFORMATION TRANSFER FORMATS IN INFRASTRUCTURE SECTOR
}

\author{
*Heikkilä, R. \\ University of Oulu \\ Erkki Koiso-Kanttilankatu 1 \\ Oulu, Finland \\ (*Corresponding author: rauno.heikkila@oulu.fi) \\ Liukas, J. \\ Sito Oy \\ Espoo, Finland \\ Karjalainen, A. \\ WSP Finland Oy \\ Oulu, Finland
}

\begin{abstract}
Fluent information exchange between different work phases, software and systems used in infra construction is a key for successful execution of infra construction projects. Open and publicly available information formats with the determined data models aim to facilitate the interoperability between different software and systems developed by competitive vendors. While building and construction industry has developed and used IFC format for years, infrastructure sector has just recently started to target clear efforts on the development of open information formats for infra construction processes. In the paper, a new Inframodel3 extension just developed in Finland and based on the LandXML1.2 international standard is to be introduced. The aim of the Inframodel 3 was set to meet the requirements of information transfer needed especially between BIM based design software, measurement systems and 3-D machine control systems used in road, railway and watercourse construction projects. Some test results are reported and evaluated in the paper. In the field of bridge engineering, the IFC format and IFC Bridge extension have been tested and evaluated in Finland. The results from the experiments show and verify as well the applicability of these open formats to the information exchange requirements in bridge engineering. The current limits for open information transfer of these formats are shown. The active co-operation with the International Building SMART Organization has led to the achieved status and position for both the Inframodel 3 and IFC Bridge formats and hence the continuing international support provided by Building SMART.
\end{abstract}

\section{KEYWORDS}

BIM, Open Information Transfer, Open Format

\section{INTRODUCTION}

Information exchange between different work phases, software and systems used in infra construction is a key for successful execution of infra construction projects. Open and publicly available information formats with the determined data models aim to facilitate the interoperability between different software and systems developed by competitive vendors. While building and construction industry has developed and used IFC format for years, infrastructure sector has just recently started to target clear efforts on the development of open information formats for infra construction processes.

Information modeling in bridge engineering has become more common in recent years. Modeling have been used mostly in detailed design stage using modeling applications to produce detailed model of 
structure, structure members, connections. The models have been used to produce workshop and other drawings to service construction work, as well as to take quantity takeoff.

However, the key idea for modeling is to model information and share and transfer that information between project participants. For buildings usage of open data transfer between architectural and engineering design and construction have increased a lot recently. The reason for that is that project participants have started to use more and more modeling but also that in many countries public organizations have created guidelines for modeling and open standard based data transfer and so also started to require modeling in project process.

For bridges same kind of modeling applications than buildings have been used but there are not common detailed guidelines how modeling should be used. Finland is one country where first version of public manual for bridge information modeling, "Siltojen tietomalliohje" (a.k.a. guidelines for bridge information modeling) have been published by the Finnish transport Agency but these guidelines does not solve question of open standard based data transfer in detailed level.

Inframodel 3 (IM3) on kansallinen sovellusohje, joka perustuu LandXML-organisaation julkaisemaan LandXML v1.2 tiedonsiirtostandardiin. Sovellusohje kuvaa osakokonaisuuksittain maarakentamisen tiedonsiirrossa käytettävän Inframodel-tiedonsiirron tarkemman sisällön ja sen esitystavan. Sovellusohjeesta on tarjolla myös vanhempi LandXML v1.0 -tiedonsiirtostandardin mukainen toteutus, joka on ollut käytettävissä eri tilaajien hankkeissa. IM2 julkaistiin vuonna 2010 ja PRE-ohjelman InfraFINBIM -työpaketissa on laadittu (valmistuu 10/2012) IM3 spesifikaatio käyttöönotettavaksi.

Inframodel 3-spesifikaatio on tarkoitettu ensisijaisesti infra-alan ohjelmistokehittäjille, jotka kehittävät LandXML v1.2 -standardin ja Inframodel 3 -sovellusohjeen mukaisia tiedonsiirron ja tiedon yhteiskäytön rajapintojen toteutuksia suomalaisille käyttäjille. Koska toteutukset ovat LandXML v1.2 yhteensopivia, nämä voivat toimia perustana tiedonsiirtototeutuksille myös kansainvälisille markkinoille.

Loppukäyttäjille spesifikaatio tarjoaa lähinnä informaatiota rajaukseen kuuluvien infrarakenteiden ja niiden ominaisuuksien suhteen. Inframodel/LandXML -toteutukset näkyvät loppukäyttäjille ohjelmistosovellusten tallennusformaattien laajennuksena. Sovelluksissa tämä näkyy, toteutuksesta riippuen, joko tallennusformaatin yhtenä vaihtoehtona normaalin tallennustoiminnon yhteydessä sekä erillisenä sisäänluku-, vienti- tai export -toimintona.

\section{METHODS}

In Finland, the development work for the open information transfer for roads, railways and waterways has recently been continued in the SWP-2 "Interfaces and standards" of the Of the Infra FINBIM work packet of the RYM PRE Process Re-Engineering research program. The aim has been to develop terminology, numbering and the next extension for the Inframodel open data transfer used in Finland.

Needs for contents of source data, data transfer from infrastructure design to bridge design and requirements of information to be included in design documents are already well known and documented and information modeling doesn't change the information flow process itself. But the key idea of information modeling is to transfer that information directly in electric and open standard format using software independent way from one application to another. Possibilities to use open standard based data transfer in bridge design and construction process was studied in that $R \& D$ project funded by Finnish Transport Agency. 


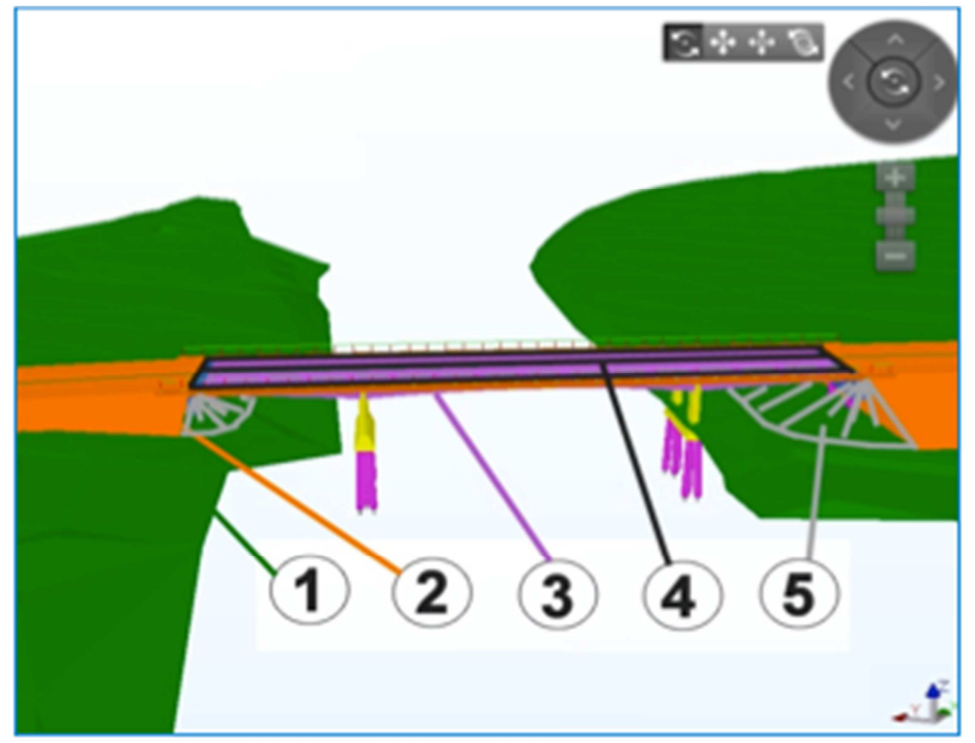

Figure 1. A draft for the solution of open information transfer for bridges.

\section{RESULTS}

A new Extension "Inframodel3" based on International LandXML standard for Open Information Transfer between all of the work phases, Building SMART cooperation and worldwide support started. The development work for the new extension of the LandXML1.2 standard has produced the first draft of Inframodel3. The format has been published in the open web page (http://www.infrabim.fi/infrabim_uusi/inframodel_3.html). Currently, the key software companies, Tekla Oyj (software Tekla Civil), Vianova Systems Finland Oy (Novapoint), Sito Oy (CityCAD) and Bentley Finland (Inroads) are implementing the export and import tools needed. The participation of other technology companies is supported by arranging different co-operative workshops with Infra FINBIM key partners and identified main technology companies as well as offering information available for the whole industry through a public web site (http://www.infrabim.fi/infrabim_uusi/index.html). The international Building SMART organization has 2012 accepted this Finnish extension for LandXML1.2 standard to be internationally supported for open information transfer purposes. Building SMART organization has 2012 accepted this Finnish extension for LandXML1.2 standard to be internationally supported for open information transfer purposes.

In the field of bridge engineering, the main results of the study are:

1) The LandXML is nowadays the most common open standard for civil (road, rail) data. Many civil engineering applications are supporting LandXML based data export and import but softwares used in bridge engineering doesn't support many advanced solutions to exploit direct link to LandXML.

2) The IFC format is in wide use for buildings and IFC can also be used to publish bridge models. However IFC standard doesn't include many bridge specific entities. 

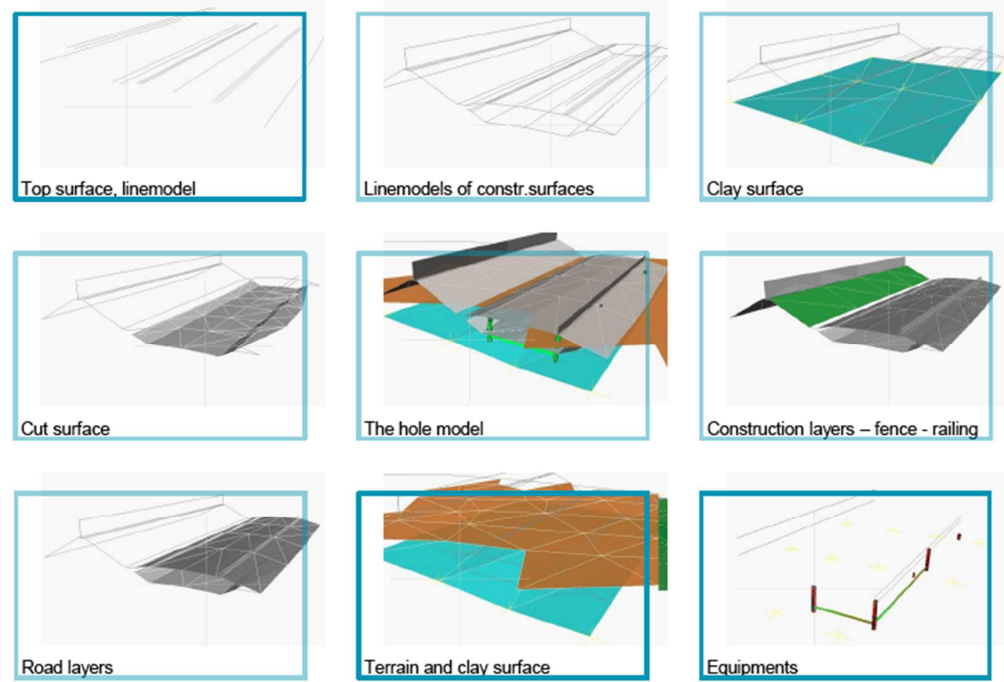

Figure 2. Examples of Inframodel3 transfer files.
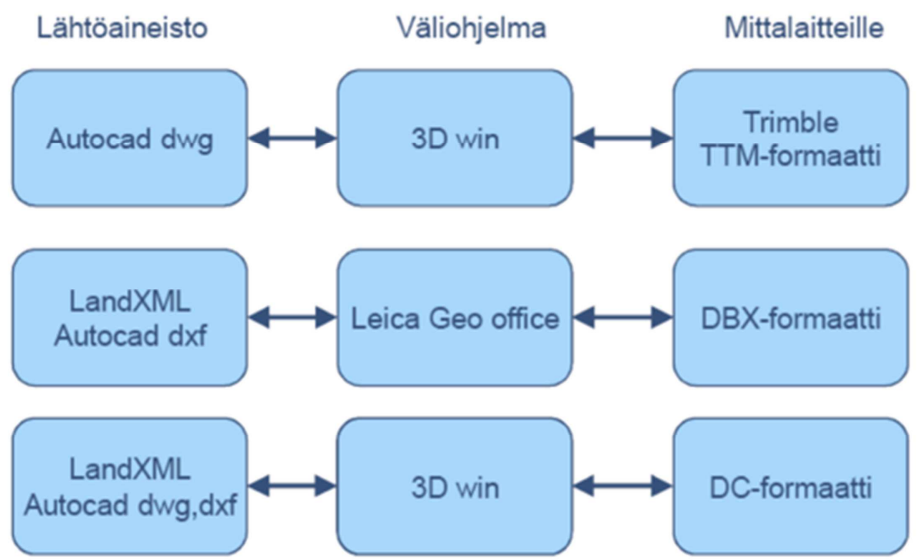

Figure 3. An example - Current situtation of the open information transfer for the measurement equipment. 

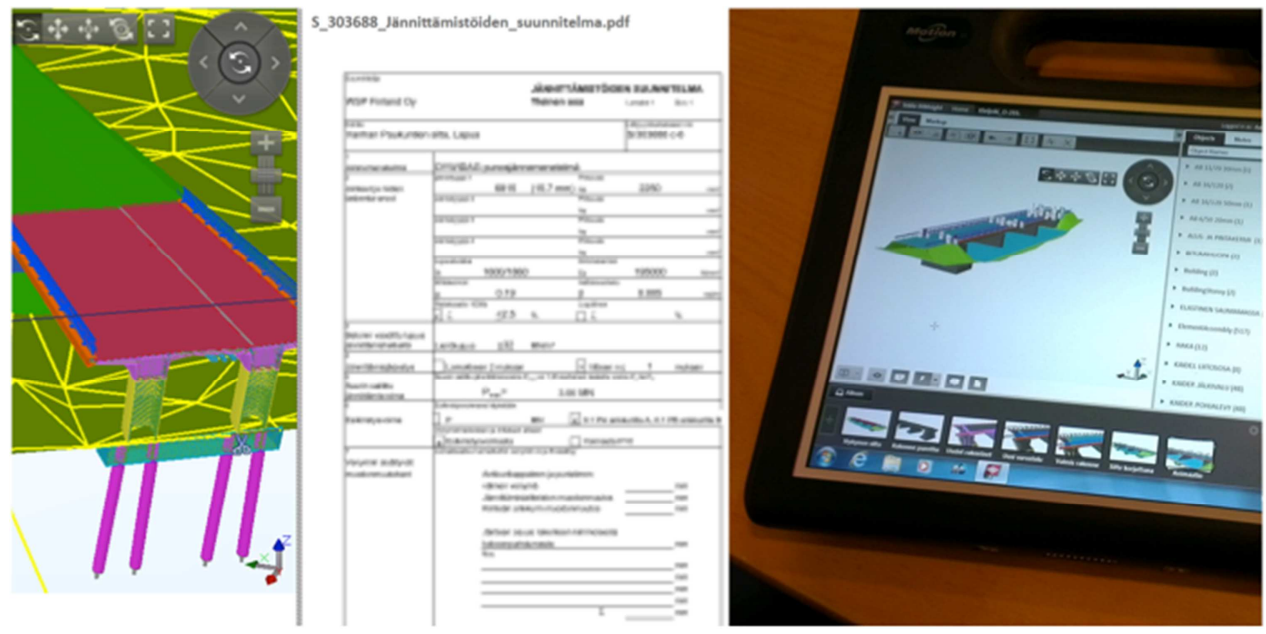

Figure 4. Experimenting open information transfer in bridge engineering.

\section{CONCLUSIONS}

Open information transfer formats will play the key roles when trying to improve the information transfer between work phases, individual software and systems. More and more international cooperation will be need in this development.

To solve "the big picture" of open standard data transfer for bridge information modeling would be to continue to develop IFC-bridge extension and get that implemented to official IFC standard. IFCbridge proposal, created 2007, is including many bridge specific technical solutions which creates possibilities to transfer that specific data especially between engineering applications; structural analysis, detailed information modeling and site engineering. Still IFC-bridge need to be developed to cover more structural types for bridges. Another important part of model based bridge engineering is link to other civil structures; mainly soil, road and rail. In near future possibilities to develop LandXML standard should be studied and solutions to be implemented in application. However, goal for long term development would be develop openINFRA concept and to implement LandXML to be part of IFC and other standard (IFD, IDM) managed by buildingSMART organization. Open standard data transfer, instead of using native models, seems also to solve many IPR (intellectual property rights) challenges which are nowadays inducing limitations to flexible information flow.

Avoin tiedonsiirto

on avain tietomallipohjaiseen tiedonsiirtoon

ratkaisee tekijänoikeuskysymyksiä

sisältää tarvittavan tiedon ja siten voi korvata dokumenttipohjaisen toimintatavan

Siltojen avoin tiedonsiirto

Mahdollistaa ohjelmistoriippumattoman mallipohjaisen suunnitteluprosessin: yleissuunnitelma $\quad$-> rakennelaskelmat -> rakennussuunnittelu $->$ tuotantosuunnittelu

IFC toimii hyvin mutta...

Siltojen tiedonsiirtoon tarvitaan

IFC-Bridge+, nimikkeistöltään ja rakennetyypeiltään laajennettu IFC 
Mallinnus- ja koordinointityökalujen kehitys

Analyysiohjelmistojen kehitys

Rakennussuunnitteluohjelmistojenkehitys

\section{REFERENCES}

